\title{
EFFECT OF YEAST CULTURE ON GROWTH PERFORMANCE AND CARCASS CHARACTERISTICS OF DAMASCUS KIDS \\ Hafez, Y. H. ${ }^{1}$; A.M.M. Zeid ${ }^{2}$; Hafsa F.H. Youssef ${ }^{1}$ and A. Sallam ${ }^{1}$ \\ 1. Sheep and Goat Research Department, Animal production Research Institute (APRI), Agriculture Research Center (ARC), Giza, Egypt. \\ 2. Animal Nutrition Department, APRI, Agriculture Research Center (ARC), Giza, Egypt.
}

\begin{abstract}
Twenty eight Damascus kids weighed $16.5 \pm 0.219 \mathrm{~kg}$ on average were used in feeding trial for 135 days. Animals were divided into four similar groups ( 7 head each) to study the effect of feeding supplemented rations with yeast culture to growing kids on its performance and carcass characteristics. Four experimental animal groups received four experimental rations as follows:

Treatment $-1\left(T_{1}\right): 2 \%$ of LBW concentrate feed mixture $+0.5 \%$ of LBW berseem hay along wheat straw ad-lib. (control ration)

Treatment-2 $\left(\mathrm{T}_{2}\right)$ : control ration $+5 \mathrm{gm}$ Moreyeast $(\mathrm{Y}) /$ head/day

Treatment-3 $\left(\mathrm{T}_{3}\right)$ : control ration $+1 \mathrm{gm}$ yeast with selenium $(\mathrm{YS}) /$ head/day

Treatment-4 $\left(\mathrm{T}_{4}\right)$ : control ration $+2.5 \mathrm{gm}(\mathrm{Y})+0.5 \mathrm{gm}(\mathrm{YS}) / \mathrm{head} / \mathrm{day}$

The results obtained can be summarized as follow:

1-Using yeast culture as feed additive was not affected on different nutrient contents in experimental rations, however total DM intake was increased with supplemented rations with yeast than that in control one.

2-Animals fed tested rations (containing yeast culture) appeared to higher in total and daily gains especially with $\left(\mathrm{T}_{3}\right)$ which get the best daily gain by about $33.67 \%$ as compared to control group.

3-Animals fed $\left(T_{3}\right)$ containing $1 \mathrm{gm} \mathrm{YS/head/day} \mathrm{recorded} \mathrm{the} \mathrm{most} \mathrm{economical}$ efficiency 3.27 and 2.19 according to year 2009 and 2011, respectively. This group had the lowest feed cost to get one $\mathrm{kg}$ gain, being 7.65 and 13.68 LE for the respective time compared with the other groups.

4-Animals fed $T_{3}$ and $T_{4}$ tended to be higher in serum glucose level compared with animals fed $T_{2}$ and $T_{1}$ (control group).

5-Using YS $\left(T_{3}\right)$ lead to be increase in dressing percentage and then edible offals such as heart, spleen, defatted kidney and tests. Moreover, increase in meat percentage was recorded than other treatment and control.

Generally, using yeast culture as feed additives in feeding of growing kids tended to be higher in total and daily gains with lower feed cost to get one $\mathrm{kg}$ gain.

Moreover, yeast plus selenium supplementation to rations of growing kids tended to higher in both hot carcass and dressing percentage.

Keywords: Damascus kids, growth, yeast culture, carcass
\end{abstract}

\section{INTRODUCTION}

The use of Saccharomyces cerevisiae as a growth promoter for ruminants was first reported in 1925 (Eckles and Williams, 1925). The mechanism in which yeast culture act to enhance animals productivity was unclear until recently. During the past ten years, specific yeast strains of Saccharomyces cerevisiae were found to be active in the rumen (Dawson et 
al.,1990). Strains of yeast differed in their ability to increase the number of viable ruminal bacteria in vitro and in vivo. Yeast culture is able to stimulate specific bacterial populations in the rumen leading to increased fiber digestion and lactate utilization (Girard et al., 1993). Robinson (1997) suggest that yeast culture does not improve NDF digestibility in low quality roughages, but it does in alfalfa hay. Gado et al. (1998) found that supplementation of yeast culture (Saccharomyces cerevisiae) in Egyptian Baladi male goats improved average daily gain. Salem et al. (2000) showed that average daily gain was improved by yeast culture supplementation when fed growing crossbreed lambs with $3 \mathrm{gm} /$ head /day yeast culture for three months. On the other hand, Drennon and Moloney (1993) and Kamalamma et al. (1996) observed that the body weight was not affected significantly by the yeast culture supplemented in the diet. According to Crosby (1995), there is a quadratic ( $p$ $<0.001$ ) effect of yeast culture dosage on protozoa population showing a greater population by using $3 \mathrm{~g} / \mathrm{day}$ of yeast culture in sheep fed on cornstover diet. While, Angeles et al. (1998) found that ruminal protozoa population was not affected by Saccharamyces cerevisiae. Mir and Mir (1993) fed steers on level $10 \mathrm{~g}$ yeast culture (SC)/head/day with three diets consisted of $75 \%$ alfalfa silage and $25 \%$ barley, $96 \%$ corn silage and $4 \%$ soybean meal or $75 \%$ rolled barley and $25 \%$ alfalfa hay. They showed that yeast culture supplementation did not alter carcass characteristics, however, carcasses of steers fed yeast were heavier than that fed control ration. Lion area and dressing percentage of steers fed yeast were consistently better than those fed control ration, but the effect was not significant. Salem et al. (2000) found that yeast culture additive with $3 \mathrm{~g} /$ head/day to lambs ration for 90 days was improve carcass weight and slaughter weight.

Recently, yeast culture as feed additives are widely used to increase growth rate, improve animal performance and productivity. The usefulness of such supplements have been depends on the specific nutrient requirements of the animal, the nature of the feed material, management practices, the health and physiological status of the animal, and the economic returns associated with the use of the supplement. In order to obtain the full benefits of a particular feed supplement, it is necessary to have a basic understanding of the mechanisms which account for its ability to improve animal production.

The present study was conducted to examine the effect of addition yeast (sacchararomyces cerevisiae) without or with selenium to the kids diet on growth performance, carcasses characteristics and some blood parameters under Egyptian conditions.

\section{MATERIALS AND METHODS}

This study was carried out at Sakha Experimental Station (Kafer ElSheikh Governorate) belonging to Animal production Research Institute, Ministry of Agriculture.

Twenty eight Damascus kids were selected with average age of 3 - 4 months old and $16.5 \pm 0.219 \mathrm{~kg}$ weight. The animals were divided into four similar groups (7 animals each) to study the effects of yeast culture 
supplemented rations on kids performance and carcass characteristics. All animals were fed $2 \%$ of LBW concentrate feed mixture, $0.5 \%$ of LBW berseem hay and wheat straw ad lib.

Four experimental animals groups were fed four different experimental rations as follow:

Ration- 1 (T1): $2 \%$ of LBW concentrate feed mixture $+0.5 \%$ of LBW Berseem hay + wheat straw as ad lib. (control ration).

Ration-2 (T2): control ration +5 gm Moreyeast $(\mathrm{Y}) /$ head /day.

Ration-3 (T3): control ration $+1 \mathrm{gm}$ yeast selenium (YS) /head/day.

Ration-4 (T4): control ration $+2.5 \mathrm{gm}$ Moreyeast $+0.5 \mathrm{gm}$ yeastselenium/head/day.

Ingredients of concentrate feed mixture were shown in Table (1).

Table (1): Ingredient of concentrate feed mixture and calculated nutritive value used in feeding trial.

\begin{tabular}{|l|c|c|c|}
\hline \multirow{2}{*}{ Ingredients } & \multirow{2}{*}{$\%$} & \multicolumn{2}{c|}{ Calculated feeding value } \\
\cline { 3 - 4 } & & TDN\% & DCP\% \\
\hline Yellow corn & 35 & 28.00 & 2.06 \\
\hline Undecorticated cotton seed meal & 25 & 15.00 & 7.65 \\
\hline Wheat bran & 15 & 9.45 & 0.97 \\
\hline Rice bran & 12 & 7.80 & 1.08 \\
\hline Soybean meal & 5 & 3.75 & 1.75 \\
\hline Molasses & 5 & 2.70 & 0.22 \\
\hline Limestone & 2 & & \\
\hline Common salt & 1 & & 13.52 \\
\hline * calculated from A.P.R.I. (1997) & 100 & 66.70 & \\
\hline
\end{tabular}

The animals were weighed at the beginning of the trial and then biweekly. Damascus kids were fed for 3 weeks as a transitional period on the experimental rations before the start of the experimental work. The experiment feeding period lasted 135 days, during which the water was available all time and the rations were offered twice daily at 8 am and $3 \mathrm{pm}$. Amounts of consumed feed were recorded. Feed conversion and economical efficiencies were calculated.

The animals were fed to cover the requirements for growth according to NRC (1985).

At the beginning and end of experimental trial, blood samples were collected from the jugular vein before feeding from all animals. The separated serum was directed analysis to enzymes activity determination, while the other part was stored frozen at $-20 \mathrm{C}{ }^{\circ}$ till the biochemical analysis. Commercial kits were used for all calorimetrical determination.

Economic efficiency was calculated as total output / total input according to the local prices.

\section{Slaughter test:}

At the end of the trial, three animals from each group were randomly chosen and weighed on three successive days after being fasted for 16 hours, and then slaughtered. 
Hafez, Y. H. et al.

Slaughtered animals were skinned, dressed out and the hot carcass was weighed. Weights of each of the heart, liver, spleen, kidneys and the fat as well as the tests were estimated. Samples of eye muscle and samples of feed intake were prepared for chemical analysis according to A.O.A.C. (1990).

Data were statistically analyzed according to Statistical Analysis System Users Guide, (SAS), (1998). Separation among means was carried out by using Duncan's New Multiple Range Test (Duncan, 1955).

\section{RESULTS AND DISCUSSION}

\section{Chemical composition of the ingredients of tested rations:}

Results obtained in Table (2) showed chemical composition of all nutrients for ingredient such as concentrate feed mixture (CFM), wheat straw, berseem hay and feed additives. It could be noticed that the percentages of nutrients for all different ingredients were almost in the ranges recorded by CLFF (2001). Also, data revealed that the feed additive of $Y S$ had higher protein content than that of $Y$ being, 48.52 versus $31.76 \%$ respectively.

Table (2): Chemical composition and calculated feeding value of feed ingredient

\begin{tabular}{|c|c|c|c|c|c|c|c|c|c|}
\hline \multirow{2}{*}{ Ingredients } & \multirow{2}{*}{$\begin{array}{l}\text { DM } \\
\%\end{array}$} & \multicolumn{5}{|c|}{ Composition of DM (\%) } & \multirow[t]{2}{*}{$\begin{array}{c}\text { OM } \\
\%\end{array}$} & \multicolumn{2}{|c|}{$\begin{array}{c}\text { Calculated } \\
\text { feeding value* }\end{array}$} \\
\hline & & $\mathbf{C P}$ & EE & CF & NFE & ash & & TDN & DCP \\
\hline $\begin{array}{l}\text { Concentrate feed } \\
\text { mixture }\end{array}$ & 91.22 & 15.80 & 3.69 & 12.87 & 58.99 & 8.65 & 91.35 & 66.70 & 13.52 \\
\hline Berseem hay & 90.18 & 13.52 & 2.98 & 28.94 & 41.76 & 12.80 & 87.20 & 48.00 & 7.4 \\
\hline Wheat straw & 91.66 & 4.49 & 1.58 & 37.90 & 38.36 & 17.67 & 82.33 & 44.00 & 3.36 \\
\hline \multicolumn{10}{|l|}{ Feed additives: } \\
\hline Moreyeast (Y) & 91.74 & 31.76 & 0.60 & 8.26 & 54.26 & 5.21 & 94.79 & & \\
\hline Yeast-selenium (YS) & 94.80 & 48.52 & 1.20 & 8.65 & 34.88 & 6.75 & 93.25 & & \\
\hline \multicolumn{10}{|c|}{ Calculated composition of experimental rations } \\
\hline Treatment-1 (T1) & 100 & 11.12 & 2.76 & 23.05 & 47.86 & 12.54 & 84.79 & & \\
\hline Treatment-2 (T2) & 100 & 11.58 & 2.85 & 24.47 & 49.95 & 12.62 & 88.88 & & \\
\hline Treatment-3 (T3) & 100 & 11.46 & 2.86 & 25.07 & 50.22 & 12.90 & 89.61 & & \\
\hline Treatment-4 (T4) & 100 & 12.01 & 2.99 & 25.51 & 52.24 & 13.18 & 92.85 & & \\
\hline
\end{tabular}

\section{Effect of supplementing rations with feed additives on growth} performance:

The results obtained in Table (3) showed that there were significant $(p<0.05)$ differences in both total and daily gains. Highly significant $(p<$ 0.05 ) differences were found with animals fed T3 (containing YS) followed by $\mathrm{T} 4(\mathrm{Y}+\mathrm{YS})$ in total gain and daily gain. Ration supplemented with $1 \mathrm{gm}$ YS (T3) had the highest values in total gain and daily gain being $17.66 \mathrm{~kg}$ and $131.0 \mathrm{gm}$, respectively. Data also showed that using $\mathrm{Y}$ with rate of $5 \mathrm{gm} / \mathrm{h} / \mathrm{d}$ in T2 tended to increase total and daily gain with no significant differences compared to control (Table 3). 
Generally, using yeast culture alone or with Selenium as feed additives in ration formulate of kids tended to higher in total and daily gain. The increasing weight as advantages \% recorded 13.27, 33.67 and $21.43 \%$ with animals fed rations containing $\mathrm{Y}, \mathrm{YS}$ and half amount of each of $\mathrm{YS}$ and Y, respectively, (Table 3).

Results obtained were agreement with those reported by Salem et al. (2000), Abdel-Momin et al. (2002) and El-Ashry et al. (2003) who found that feed additives (Flavomycin) for lambs had the best average body weight and daily gain followed by those fed Saccharomyces cerevisia, while the control group had the lowest average body weight gain. In this respect, Abou'l-Ella (2007) observed that, the daily gain of offspring of ewes supplemented groups significantly $(p<0.05)$ increased compared to those of control group. Also, Lesmeister et al. (2004) reported that inclusion of yeast culture with rate of $2 \%$ of the starter ration significantly $(p<0.05)$ increased average daily gain by $15.6 \%$.

Table (3): Growth performance, feed intake and feed efficiency of kids fed different experimental rations.

\begin{tabular}{|c|c|c|c|c|}
\hline \multirow{2}{*}{ Items } & \multicolumn{4}{|c|}{ Treatments } \\
\hline & T1 & T2 & T3 & T4 \\
\hline Duration of trial (day) & 135 & 135 & 135 & 135 \\
\hline No of kids & 7 & 7 & 7 & 7 \\
\hline \multicolumn{5}{|c|}{ Growth performance } \\
\hline Av. initial body weight, $\mathrm{Kg}$. & $16.00 \pm 0.79$ & $16.33 \pm 1.26$ & $16.17 \pm 1.01$ & $17.00 \pm 1.96$ \\
\hline Av. final body weight, $\mathrm{Kg}$. & $29.29 \pm 1.15$ & $31.33 \pm 1.52$ & $33.83 \pm 1.08$ & $33.14 \pm 1.65$ \\
\hline Av. total weight gain, $\mathrm{Kg}$. & $13.29^{b} \pm 0.68$ & $15.00^{\mathrm{ab}} \pm 1.32$ & $17.66^{\mathrm{a}} \pm 1.12$ & $16.14^{\mathrm{a}} \pm .1 .08$ \\
\hline Av. daily weight gain, $\mathrm{g}$ & $98.0^{\mathrm{b}} \pm 0.01$ & $111.0^{\mathrm{ab}} \pm 1.01$ & $131.0^{a} \pm 0.01$ & $119.0^{a} \pm 0.01$ \\
\hline Advantage, $\%$ & |--------- & 13.27 & 33.67 & 21.43 \\
\hline \multicolumn{5}{|c|}{ DM intake $(g / h / d)$} \\
\hline Concentrate feed mixture & 456 & 464 & 462 & 489 \\
\hline Berseem hay & 112 & 114 & 113 & 122 \\
\hline Wheat straw & 315 & 345 & 361 & 355 \\
\hline \multicolumn{5}{|l|}{ Feed additive } \\
\hline Moreyeast $(\mathrm{Y})$ & 0 & 4.6 & 0 & 0 \\
\hline Yeast-selenium (YS) & 0 & .0 & 0.94 & 0 \\
\hline Moreyeast + OSY-NRCE & 0 & 0 & 0 & 2.77 \\
\hline Total DM intake & 883.0 & 927.6 & 936.9 & 968.8 \\
\hline & \multicolumn{4}{|c|}{ Feed conversion } \\
\hline
\end{tabular}

$A$ and $b$ Means within the same row with different superscripts are significantly different at $(p<0.5)$.

\section{Effect of supplementing ration with feed additives on feed intake and efficiency:}

Data presented in Table (3), showed that total dry matter intake increased with treatments (T2), (T3) and (T4) than that of the untreated group (T1), being 927.6, 936.9, 968.8 and $883 \mathrm{gm}$, respectively. This increase in DM intake may be due to yeast supplementation to the diets, it provide factors stimulating to rumen cellulolytic bacteria when high concentrate diet was used. The same results were obtained by El-Waziry et 
al (2000) who studied the effect of supplemented yeast culture at two levels (11.25 and $22.5 \mathrm{~g} / \mathrm{head} /$ day) in sheep ration, they found that dry matter intake was increased with the two treatments compared to control diet. Also, Abou'l-Ella (2007) revealed that yeast supplementation enhanced significantly $(p<0.05)$ the total dry matter intake and utilization of roughage.

Average feed conversion expressed as $\mathrm{kg} \mathrm{DMl} / \mathrm{kg}$ gain was 9.010, 8.356, 7.152 and 8.141 for treatments (T1), (T2), (T3) and (T4), respectively. Showing improved feed conversion with animals fed tested rations (T2, T3 and T4). Moreover, animals fed (T3) were the most efficient to get more weight with less intake of feed. So, animals fed ration containing $1 \mathrm{gm}$ (YS) gave the highest daily gain (131 gm) with $33.67 \%$ as an advantage percentage (Table 3).

The results were agreement with those reported by Drennan (1990) who found that some improvement in feed conversion were found with adding yeast culture to silage as based diet to bulls. Also, El-Waziry et al (2000) studied the effect of supplemented yeast culture at two levels (11.25 and $22.5 \mathrm{gm} /$ head / day) in sheep ration, they found that dry matter was increased with two treatments of yeast culture compared to control. Ibrahim et al (2002) found that feed conversion was significantly better $(p<0.05)$ for goats fed ration supplemented with commercial microbial supplement than those received the un-supplemented ration. However, differences in feed conversion among control and moreyeast diets were not significant. On the other hand Abou'l -Ella (2007) revealed that supplemented ration with yeast culture enhanced significantly $(p<0.05)$ the total DM intake and more utilization of roughage.

With respect to feed cost and economical efficiency (Table 4), it could be noticed that the animals fed T1 showed the highest feed cost and the lowest economical efficiency. While, animals fed ration containing YS (T3) tended to be lowest feed cost and the highest economical efficiency, followed by those fed T4 and then T2, respectively compared with those fed control ration (T1) according to 2009 and 2011.

Effect of supplemented ration with feed additives on blood profile:

Data presented in Table (5) recorded that animals fed ration (T3) containing $1 \mathrm{gm}$ YS tended to be higher glucose, total protein and albumin concentration, being $60.62,8.00$ and 4.83 , respectively compared with other groups. Supplement YS to ration (T3 and T4) resulted in higher concentration of glucose, total protein and albumen. Higher significant $(p<0.05)$ differences were found in glucose concentration with $\mathrm{T} 3$ and T4, respectively.

On the contrary, supplementing feed additives to tested rations was not affected on urea concentration, as show on Table (5).

It could be noticed that, total protein, albumin and globulin concentration appeared to somewhat higher with feed additive (T2, T3 and T4) compared to control with no significant difference.

Data concerning about the enzyme activity (AST and ALT concentration), shown that yeast with selenium in T3 and T4 had recorded the lowest values in AST than those fed T2 and control. 
Table (4): Feed cost and economic efficiency of different experimental rations.

\begin{tabular}{|c|c|c|c|c|}
\hline \multirow{2}{*}{ Items } & \multicolumn{4}{|c|}{ Treatments } \\
\hline & T1 & T2 & T3 & T4 \\
\hline \multicolumn{5}{|c|}{ Av. daily feed intake as fed (gm/head) } \\
\hline Concentrate feed mixture & 499 & 509 & 506 & 536 \\
\hline Berseem hay & 124 & 126 & 125 & 135 \\
\hline Wheat straw & 344 & 376 & 394 & 387 \\
\hline Moreyeast $(\mathrm{Y})$ & 0 & 5 & 0 & 0 \\
\hline Yeast-selenium (YS) & 0 & 0 & 1 & 0 \\
\hline Y+YS & 0 & 0 & 0 & 3 \\
\hline Total feed intake & 967 & 1016 & 1026 & 1061 \\
\hline Av. daily gain (gm) & 98.0 & 111.0 & 131.0 & 119.0 \\
\hline Av. feed cost/kg gain (LE) ${ }^{*}(2009)$ & 9.96 & 9.03 & 7.65 & 8.87 \\
\hline Economical efficiency ${ }^{\star}$ & 2.51 & 2.77 & 3.27 & 2.82 \\
\hline Av. feed cost/kg gain (LE) ${ }^{\star \star}(2011)$ & 17.44 & 16.55 & 13.68 & 15.98 \\
\hline Economical efficiency $^{\star \star}$ & 1.72 & 1.81 & 2.19 & 1.88 \\
\hline \multicolumn{5}{|c|}{$\begin{array}{l}\text { * Based on the assumption that the price of one ton of CFM was } 1500 \mathrm{LE} \text {; berseem hay } \\
\text { was } 1000 \mathrm{LE} \text {, wheat straw was } 300 \mathrm{LE} \text {, one } \mathrm{kg} \text { of moreyeast was } 12 \mathrm{LE} \text {, one } \mathrm{kg} \text { yeast } \\
\text { with Selenium was } 22 \mathrm{LE} \text {, while one } \mathrm{kg} \text { body weight as selling was } 25 \mathrm{LE} \text {. (according to } \\
2009 \text { ) } \\
\text { ** Based on the assumption that the price of one ton of CFM was } 2500 \mathrm{LE} \text {; berseem hay } \\
\text { was } 1500 \mathrm{LE} \text {, wheat straw was } 800 \mathrm{LE} \text {, one } \mathrm{kg} \text { of moreyeast was } 15 \mathrm{LE} \text {, one } \mathrm{kg} \text { yeast } \\
\text { with Selenium was } 25 \mathrm{LE} \text {, while one } \mathrm{kg} \text { body weight as selling was } 30 \mathrm{LE} \text {. (according to } \\
\text { 2011) }\end{array}$} \\
\hline
\end{tabular}

Table (5): Blood profile of animals fed different tested rations during experimental period

\begin{tabular}{|l|c|c|c|c|}
\hline \multicolumn{1}{|c|}{ Treatment } & T1 & T2 & T3 & T4 \\
\hline Glucose (mg/dl) & $53.00^{\mathrm{b}} \pm 1.69$ & $51.89^{\mathrm{b}} \pm 2.93$ & $60.62^{\mathrm{a}} \pm 1.87$ & $59.63^{\mathrm{a}} \pm 1.99$ \\
\hline Urea (mg/dl) & $38.89 \pm 2.53$ & $36.58 \pm 2.83$ & $36.37 \pm 3.74$ & $34.54 \pm 2.61$ \\
\hline Creatinine (mg/dl) & $1.24 \pm 0.15$ & $1.09 \pm 0.10$ & $1.23 \pm 0.14$ & $1.08 \pm 0.13$ \\
\hline Total protein (g/dl) & $7.17 \pm 0.18$ & $7.59 \pm 0.37$ & $8.00 \pm 0.35$ & $7.85 \pm 0.30$ \\
\hline Albumin (g/dl) & $4.29 \pm 0.08$ & $4.34 \pm 0.24$ & $4.83 \pm 0.28$ & $4.71 \pm 0.32$ \\
\hline Globulin (g/dl) & $2.88 \pm 0.06$ & $3.25 \pm 21$ & $3.17 \pm 0.22$ & $3.14 \pm 0.26$ \\
\hline AST (IU/L) & $16.43 \pm 1.69$ & $17.00 \pm 1.57$ & $15.83 \pm 1.89$ & $15.43 \pm 1.29$ \\
\hline ALT (IU/L) & $33.29 \pm 1.64$ & $32.17 \pm 1.62$ & $32.50 \pm 1.52$ & $33.14 \pm 1.37$ \\
\hline
\end{tabular}

and $b$ Means within the same row with different superscripts are significantly different at $(p<0.5)$.

The results were agreement with those reported by abdel- Khalek et al (2000). They found that significantly $(p<0.05)$ increase in plasma total protein, albumin and glucose concentrations for animals fed Lacto - Sacc compared with control ration. El- Ashry et al (2002) indicated that plasma total protein and globulin concentration tended to increase while plasma urea tended to decrease with tested ration. On the other hand, El- Ashry et al (2003) found that adding flavormycine and Saccharomyces cervisiae increased $(p<0.05)$ total protein, albumin, globulin, creatinine, AST and ALT than control ration. The same previous trend was observed by Abou'l -Ella (2007) who found that the total protein and globulin concentration tended to be higher in supplemented ration with feed additives. 
Hafez, Y. H. et al.

Effect of supplemented ration with feed additives on carcass characteristics:

Results of hot carcass weight, dressing percentages and some carcass traits were presented in Table (6). It could be noticed that hot carcass weight recorded $15.19,16.46,17.29$ and16.74 kg with treatments T1, T2, T3 and T4, respectively, showing higher hot carcass weight with tested rations (T2, T3 and T4) compared with control ration.

Table (6): The effect of yeast culture on carcass characteristics

\begin{tabular}{|l|c|c|c|c|}
\hline \multicolumn{1}{|c|}{ Treatment } & T1 & T2 & T3 & T4 \\
\hline Fasting body weight, $\mathrm{Kg} \mathrm{(A)}$ & $31.00 \pm 2.51$ & $32.67 \pm 3.18$ & $33.33 \pm 1.86$ & $32.33 \pm 0.33$ \\
\hline Empty body weight, $\mathrm{Kg} \mathrm{(B)}$ & $27.99 \pm 1.60$ & $29.66 \pm 3.27$ & $30.37 \pm 1.38$ & $28.44 \pm 0.61$ \\
\hline Hot carcass weight, $\mathrm{Kg}(\mathrm{C})$ & $15.19 \pm 1.17$ & $16.46 \pm 1.88$ & $17.29 \pm 0.99$ & $16.74 \pm 0.67$ \\
\hline Dressing (C/A), \% & $49.03 \pm 0.29$ & $50.27 \pm 2.17$ & $51.89 \pm 1.26$ & $51.74 \pm 1.53$ \\
\hline Dressing (C/B), \% & $54.16 \pm 1.21$ & $55.50 \pm 2.29$ & $56.95 \pm 2.30$ & $58.82 \pm 1.32$ \\
\hline Edible offals, Kg : & \multicolumn{5}{|l|}{} \\
\hline Hart & $0.18 \pm 0.01$ & $0.17 \pm 0.02$ & $0.21 \pm 0.02$ & $0.18 \pm 0.03$ \\
\hline Liver & $0.59 \pm 0.04$ & $0.57 \pm 0.01$ & $0.57 \pm 0.01$ & $0.61 \pm 0.03$ \\
\hline Spleen & $0.05 \pm 0.01$ & $0.06 \pm 0.01$ & $0.07 \pm 0.01$ & $0.06 \pm 0.01$ \\
\hline Defatted kidneys & $0.10 \pm 0.01$ & $0.11 \pm 0.01$ & $0.11 \pm 0.01$ & $0.11 \pm 0.00$ \\
\hline Tests & $0.22 \pm 0.02$ & $0.34 \pm 0.10$ & $0.30 \pm 0.05$ & $0.37 \pm 0.14$ \\
\hline
\end{tabular}

Estimated dressing percentage based on both fasting body weight and empty body weight appeared to have higher with tested rations. So, using $Y$ or YS as feed additive attainted to higher carcass weight and dressing percentage, as shown in Table (6).

On the other hand different edible offals were not affected by using feed additive, but using a half a mount of $Y$ and $Y S$ in (T4) showed some what higher in edible offalis weights with no significant differences.

Data were agreement with those reported by Salem et al (2000) who found that growing lambs on yeast culture $(3 \mathrm{gm} / \mathrm{h} / \mathrm{d})$ attained to improve in carcass weight, slaughter weight and carcass characteristics .Also ,Khattab et al (2003) showed that dressing percentage and hot carcass weight were $((p<0.05)$ improved with yea-Sacc and lacto - Sacc gropes .

Effect of supplemented ration with feed additive on chemical analysis of carcass:

Data presented in Table (7) revealed that increasing both meat \% and bone $\%$ with decreasing fat $\%$ in carcass of animals fed tested rations $\left(T_{2}, T_{3}\right.$ and $\mathrm{T}_{4}$ ).

The previous trend was correlated with analysis of eye muscle. Moreover, ash content of eye muscle of animals fed tested ration was higher than those fed control ration.

From these results, it could be noticed that animals fed ration containing feed additive had higher hot carcass, decreasing percentage, meat percentage and bone percentage but it give lower fat \%. 
Table (7): The effect of yeast on chemical analysis of rabies

\begin{tabular}{|l|c|c|c|c|}
\hline \multicolumn{1}{|c|}{ Treatment } & T1 & T2 & T3 & T4 \\
\hline Meat \% & $59.16 \pm 1.27$ & $59.74 \pm 0.9$ & $60.58 \pm 1.10$ & $60.63 \pm 1.26$ \\
\hline Fat \% & $25.64 \pm 1.41$ & $24.30 \pm 1.11$ & $22.48 \pm 0.97$ & $22.12 \pm 1.36$ \\
\hline Bone \% & $15.20 \pm 0.51$ & $15.96 \pm 0.30$ & $16.94 \pm 0.39$ & $16.54 \pm 0.97$ \\
\hline Analysis of eye muscle $:$ & \multicolumn{4}{|l|}{} \\
\hline Moisture & $71.39 \pm 1.44$ & $71.96 \pm 1.01$ & $70.18 \pm 1.59$ & $71.63 \pm 0.70$ \\
\hline CP & $62.23 \pm 2.05$ & $64.61 \pm 2.66$ & $69.18 \pm 1.24$ & $69.45 \pm 1.70$ \\
\hline EE & $30.29 \pm 2.3$ & $27.85 \pm 3.34$ & $22.59 \pm 0.74$ & $22.12 \pm 1.39$ \\
\hline Ash & $3.40 \pm 0.11$ & $3.71 \pm 0.14$ & $3.99 \pm 0.26$ & $3.63 \pm 0.10$ \\
\hline
\end{tabular}

Generally, it could be concluded that ration containing yeast or yeast plus selenium appeared to higher crude protein and lower crude fat. Moreover, these rations gave more total and daily gains. The kids fed rations containing feed additive such as yeast plus selenium $\left(T_{3}\right)$ had more weight gain and economical efficiency with lower feed cost to get one kg gain. At the same time, there are an increase weight of hot carcass and dressing percentage. So, it could be use yeast plus selenium as feed additives in ration of growing kids to get more weight gain, less feed cost and higher carcass weight and dressing percentage.

\section{REFERENCES}

Abdel-Khalek; A. F. Mehrez and E. A. Omar (2000). Effect of yeast culture (LactoSacc) activity, blood constituents and growth of suckling Friesian calves. Proc.Conf. Anim. Prod. In The $21^{\text {th }}$ Century, Sakha, 18 - 20 April :201 210.

Abdel-Momin, M.; I.S. El-Shamaa and A. M. Metwally. (2002). Onset of puberty in ewe lambs as influenced by dietary yeast culture supplementation. J.Agric. Res. Tanta Univ., 28 (2).

Abou'l Ella, A.A.,(2007) Effect of dry yeast and /or bentonite as feed additives on productive performance of lactating ewes and its offsprings. Egyptain. J. Nutr. And Feeds. 10 (1): 81 - 98.

Angeles. S. C. C; G. D. Mendoza M; M. A. Cobos P M.M. Crosby G. F. A. Castrejon P. (1998). Comparison of two commercial yeast cultures (Saccharomyces cerevisiae) on ruminal fermentation and digestion in sheep fed on corn-stover diet. Small Ruminant Res. 31:45 - 50.

A.O.A.C.(1990). Official methods of analysis. Association of Official Analytical Chemists $15^{\text {th }}$ ed. Official Methods of Analysis. Washington, D.C., USA.

A.P.R.I. (1997). Ministry of Agriculture , ARC, APRI, Scientific and application of Animal Nutrition, $1^{\text {st }}$ press.

Central Lab for Food and Feed (2001). Feed Composition Tables for Animal and poultry feedstuffs used in Egypt. Technical Bulletin of central Lab for food and feed, No. 1, Giza, Egypt.

Crosby, M. M. (1995). Efecto de la dosis de un cultivo de levadura (Saccharomyces cerevisiae) en la fermentaction y en la digestibilidad ruminal de la fibra en borregas. Tesis Maestria. Colegio de Postgraduos. Programa de ganaderia. Montecillo, Estado de Mexico. (Summary) 
Dawson K.A. (1990). Designing the yeast culture of tomorrow-mode of action of yeast culture for ruminants and non-ruminants. Biotechnology in the Feed Industry, Proceeding of Altech's Sixth Annual Symposium. Edited by T.P. Lyons, Altech Technical Publications, 3031 Catnip Hill Pike, Nicholasville.

Dawson, K.A.; K. E. Newman and J.A. Boling , (1990 ). Effect of microbial supplements containing yeast and lactobacilli on roughage-fed ruminal microbial activities. J. Anim. Sci., 63: $3392-3398$.

Drennan, M. (1990). Effect of Yea-Sacc on feed intake and performance of finishing bulls. In Biotechnology in the feed industry (ed.T.P.Lyons),p.495.Alltech Technical Publication, Nicholasville, Kentucky.

Drennan, M. J and A. P. Moloney (1993). Effect of yeast culture on growth of beef cattle fed on grass silage plus barley based concentrates Irish. J. Agric. And Food Research, 32: 25.

Duncan, D.B. (1955). Multiple range and multiple F-test Biometerics, 11-1.

Eckles, C. h. and V. M. Williams (1925). Yeast as a supplementary feed for lactating cows. J. Dairy Sci. 8:89. Kentucky,40356, pp 65-75.

El-Ashry. M.A; Zeba A.Motagally and Y. A.Maareck (2002). Effect of live dried baker,s yeast with or without acidification of milk and yeast culture on performance of suckling buffalo calves. Egypptian J. Nitrition and Feeds. 5 (1):31-41.

El-Ashry, M. A; Afaf, M. Fayed; K. M, Youssef; F. A. Salem and Hend, S. Aziz.(2003). Effect of feeding flafomycin or yeast as feed supplement on lamb performance in Sinai. Egyptian J. Nutrition and feeds, 4 (special Issue): 1009

El-Waziry, A. M; H. E. Kamal and M. H. Yacont (2000). Effect of bakers yeast (saccromyces cervisiae) supplementation to berseem (Trifolium Alexandrinum) hay diet on protein digestion and rumen fermentation of sheep. Egyptain. J. Nutr. And Feeds. 3:71.

Girard, I.D., C.R. Jones, and K.A. Dawson (1993). Lactic acid utilization rumen simulating cultures receiving a yeast culture supplement. J. Anim. Sci. 71 (Suppl. 1): 288.

Gado, H. M.; A. Y. Badawi.; F. L. S. Helal and S. A. Nasr (1998). Effect of yeast culture supplementation on the growth performance of growing goats. J. Agric. Sci., Ain-Shams Univ., Cairo, $6: 123$.

Ibrahim, Fathia. A; Ahmed, M.E; Ahmed, A. El-Shewy and Faten F. Abou Ammou (2002). Effect of commercial microbial supplements on performance of lactating Zaraibi goats . Proc., $1^{\text {st }}$ Ann. Sc. Conf. Anim.\& Fish Prod. Mansoura 24\& 25 Sep.

Kamalamma, V.; O. U. Krishnon. and P, Krishnappa. (1996). Effect of feeding yeast culture (Yea-Sacc1026) on rumen fermentation in vitro and production performance in cross breed dairy cows. Animal feed Science and Technology. 57:3. 247; 24 ref.

Khattab, H. M; F. A. Salem; M. M. Sayeda and H. M. Nagh, (2003). Effect of Yeasacc supplementations and energy levels on performance, rumen activity, some blood constituents and carcass traits in growing sheep.

Lesmeister K. E., A. J. Heinrichs, and M. T. Gabler (2004). Effects of Supplemental Yeast (Saccharomyces cerevisiae) culture on rumen development, growth characteristics, and blood parameters in Neonatal dairy calves. Journal of Dairy Science, 87: 1832-1839. 
Mir, Z. and P.S. Mir (1993). Effect of the addition of live yeast culture (Saccharomyces cerevisiae) on growth and carcass quality of steers fed high-forage or high-grain diets and on feed digestibility and in situ degradability J. Anim. Sci., 72: 537.

N. R. C. (1985). Nutrient requirements of sheep 6 th revised Ed. National Academy Preoo, Washington. D. C.

Robinson, P.H (1997). Effect of yeast culture (Saccharomyces cervisiae) on adaptation of cows to diets postpartum. J. Dairy. Sci., 80: 1119.

Salem, F. A.; A. S. Soliman.; M. R. M. El-Mahdy and S. M. Abd El-Mawla (2000). Effect of some feed additives to diets of growing sheep on growing performance, rumen fermentation, blood constituents and carcass characteristics. Annals of Agric. Sci. Moshtohor, 38: 1733.

SAS (1998). Statistical analysis system. SAS User's Guide: Statistics. SAS Institute Inc. Editors, Cary, NC.

$$
\begin{aligned}
& \text { تأثير الخميرة علي النمو و صفات الأبيحة في الجداء الامشثي }
\end{aligned}
$$

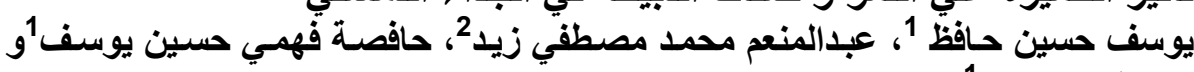

$$
\begin{aligned}
& \text { عبد العزيز سلام } 1 \\
& \text { 1- قسم بحوث تربية الاغنام و الماعز ـ معهد بحوث الانتاج الحيواني ـ مركز البحوث الزراعية ـ الجيزة }
\end{aligned}
$$

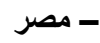

$$
\begin{aligned}
& 2 \text { - قسم بحوث تغذية الحيوان - معهد بحوث الانتاج الحيواني ـ مركز البحوث الزراعية ـ الجيزة ـ مصر }
\end{aligned}
$$

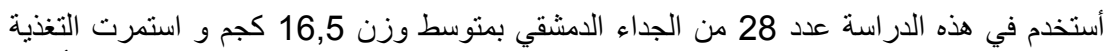

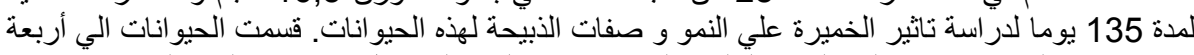

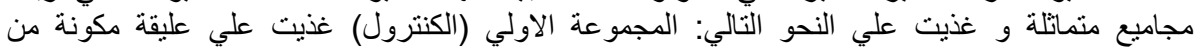

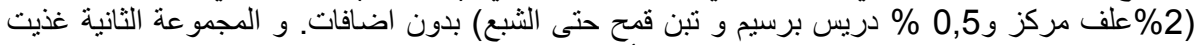

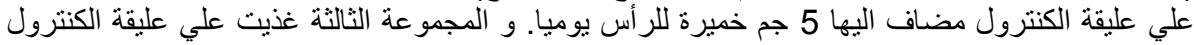

$$
\begin{aligned}
& \text { مضاف اليها } 1 \text { جم خميرة بالسلنيوم. و المجمو عة الر ابعة غذيت عليت علي عليقة مثل الكنترول مضاف اليها } \\
& \text { وم خميرة + 0,5 جم خميرة بالسلنيوم. } \\
& \text { وكانت أهم النتائج المتحصل عليرة بليها كما يلي: }
\end{aligned}
$$

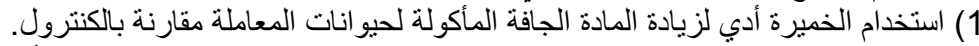

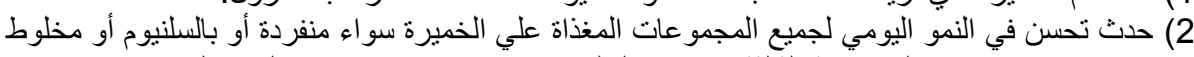

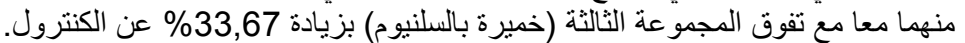

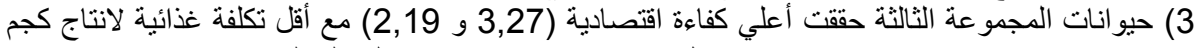

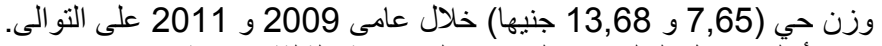

$$
\begin{aligned}
& \text { 4) وجد أعلي معدل لجلوكوز الدم في المجموعة الثالثة مقارنة بباقي حيو انات المعاملات الأخري و } \\
& \text { 5) سجلت المعاملة الثالثة أعلي نسبة تصافي للابيحة و أعلى وزن للأجزاء المأكولة (القلب و الطحال و } \\
& \text { الكلاوي) وكذللك نسبة اللحم. لكئ. }
\end{aligned}
$$

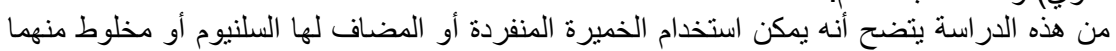

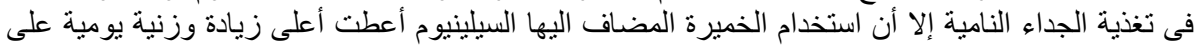

$$
\begin{aligned}
& \text { أقل تكاليف غذائية وأعلى كفاءة غذائية مع زيادة نسبة التصافى للحوم النامية . } \\
& \text { كلية الزراعة - جامعة المنصورة } \\
& \text { مركز البحوث الزراعية }
\end{aligned}
$$

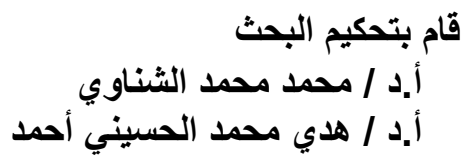

